\title{
Legal Status of Persons with Mental Disorders Under Civil Legislation of Russia and Germany
}

\author{
Tamara V. Shepel* \\ Novosibirsk National Research State University \\ 1 Pirogova Str., Novosibirsk, 630090, Russia
}

Received 22.05.2017, received in revised form 06.06.2017, accepted 09.06.2017

The article gives a comparative description of legal status of persons with mental disorders as provided for by the legislation of Russia and Germany: incapacity, limited capacity, temporary incapacity to understand the meaning of one's actions or to control them in the course of transaction or infliction of harm. The analysis of the Civil Code of the Russian Federation and the German Civil Code showed that these statuses have similar features in Russia and Germany: a) they are of a legal status; b) they are primarily caused by a mental disorder; c) they indicate a person's incapacity to understand the meaning of one's actions or control them. However, there are differences in legal regulation of these statuses: a) the number of legislatively fixed legal statuses is different; b) the terminology for a medical criterion of these statuses is different; c) the institute of incapacitation is legislated differently, etc. Yet, this does not impede the improvement of the norms of the civil law in Russia and Germany regarding these legal statuses, taking the countries' positive practice into account.

Keywords: incapacity, limited capacity, temporary incapacity to understand one's actions in the course of transactions and infliction of harm in Russia and Germany, mental disorder.

DOI: 10.17516/1997-1370-0088.

Research area: law.

No country in the world has accurate data on the prevalence of mental disorders. According to the World Health Organization, more than 450 million people suffer from mental disorders. The psychiatrists forecast a steady increase of cases of mental diseases in the world. These negative processes indicate the necessity of the development of a unified approach to ensure the effective protection of the rights of persons with mental disorders.

This approach involves the use of positive practice in civil legislation and law enforcement practice in Russia and European countries, including Germany, with regard to the protection of subjective rights and legitimate interests of citizens with mental disorders.

Mental disorders (regardless of an ability to understand one's actions) rarely involves civil law consequences in Russia and Germany. Generally, the legislator associates the occurrence of such consequences with a mental disorder that temporarily or permanently results in inability to understand one's behavior.

(c) Siberian Federal University. All rights reserved

* Corresponding author E-mail address: tomaser@mail.ru 
Only two statuses caused by mental disorders have been fixed in the Russian civil law until recently: incapacity (Article 29 of the Civil Code of the Russian Federation) and inability to understand the meaning of one's actions or to control them in the course of transaction or infliction of harm (Articles 177, 1078 of the Civil Code of the Russian Federation), referred to as incapacity in literature. The norm of the limited capacity of the mentally ill persons was not fixed in the Civil Code until March 2, 2015. Persons with mental disorders with a reduced ability to understand their behavior were considered either incapable or fully capable. The lack of a legal opportunity to limit their capacity had a negative impact on the society and did not contribute to such persons' effective protection.

In Russia the scientists have long been commenting on the need for working out the norms of incapacitation caused by a mental disorder (Blinova (Shepel), 1986; Ivanova, 1993, et al.). In Russian forensic psychiatry a whole area of research of a medical criterion of limited capacity caused by a mental disorder was formed. However, the system of the analyzed legal statuses was supplemented with another type only in March 2, 2015, the type being limited capacity. A new version of Paragraph 1 Clause 2 Article 30 of the Civil Code of the Russian Federation provides with the nomination of a mental disorder making a person incapable to understand the meaning of his/her actions or control them without the help of the others as the ground for incapacitation.

The German Civil Code (BGB) provides for two statuses caused by a painful disorder of mental activity that excludes the freedom of expression, the statuses being incapacity (\& 104 BGB) and unconscious state or temporary disorder of mental activity in the course of transaction (\& 105 (2) BGB) or infliction of harm (\& 827 BGB). Disorders of psychical activity as a separate ground of incapacitation are not mentioned in the current BGB. Paragraph 6 BGB, in which the following grounds were stated: a) mental illness or deficiency of face leading to inability to manage one's own affairs; b) a person's extravagance leading to his/her or his/her family's difficult financial situation; c) alcoholism or drug addiction resulting in a citizen's inability to manage his/her affairs, his/her and (or) his/her family's difficult financial situation, threats to the security, is cancelled now. Thus, in Germany as in several other countries (Austria, Belgium, France, etc.) the institute of incapacitation of the mentally ill was not legalized. However, this is not an indication of actual impossibility of such restriction. The court is granted the right to define various limits of restricting a person's civil rights depending on the degree of mental disorder. In my opinion, the German approach is more consistent with the interests of persons with mental disorders which differ in their severity and duration. In contrast to hard and fuzzy criteria of incapacitations specified in the Civil Code of the Russian Federation, flexible rules allow the courts to individualize the degree of the capacity loss and differentiate legal implications depending on this.

The term "status" seems to be the best to denote the civil-legal phenomena mentioned. The relevance of this term is primarily due to the use of the word "sostoianie" ("state", "condition") in the Russian legislation to characterize not only incapacity (Clause 1 Article 177, Paragraph 1 Article 1078 of the Civil Code of the Russian Federation) but the related phenomena of insanity (Article 21 of the Criminal Code of the Russian Federation; Article 2.8 of the Code of Administrative Offences of the Russian Federation), inability of the taxpayer to give an account of his/her actions or control them (Paragraph 2 Article 111 of the Tax Code of the Russian Federation). This term is also used in BGB to refer to a specific situation of a 
citizen with mental disabilities. In all the cases the content of legal statuses caused by mental disorders reflects the range of a person's capacity based on the characteristics of mind and will.

The civil statuses caused by a mental disorder are characterized by a number of peculiar features.

1. They are legal statuses. Unfortunately, the rules in the Civil Code of the Russian Federation and the BGB put emphasis not on legal but on medico-psychological characteristics. Legal characteristics of these statuses are not stated at all. At the same time the Russian legislator defines the capacity (the concept of capacity is missing in BGB) as a legal category - an ability to acquire civil rights, create civil obligations for oneself and execute them by one's actions (Clause 1 Article 21 of the Civil Code of the Russian Federation). Its biological preconditions (normal mental condition, attainment of a certain age as well as psychological conditions as an ability to understand the meaning of one's actions or control them) are not included in the formula of capacity.

Comparison of the concepts of legal capacity and legal statuses under consideration may lead to the impression that the law considers different, totally non-comparable legal phenomena. In fact, the uniting feature is that they are an individual's integral legal properties. In this regard, the definitions of these concepts should contain the legal attribute, which can be generally defined as a person's inability to fully produce legal effects, stipulated by the law, by his/her actions (Shepel, 2006).

2. The mentioned statuses are generally caused by a mental disorder. In the legislation of Russia and Germany they are termed differently. In Russia the term "mental disorder" is used, in Germany the term applied is "a painful disorder of mental activity" or "unconscious state or state of temporary disorder of mental activity".
Russia and Germany are guided by the Statistical classification of diseases and related health problems, 10th revision ${ }^{1}$. It suggests using the term "mental disorder" as a clinically defined group of symptoms or behavioral traits that cause suffering and prevent from personal functioning in most cases. So, the terminology of Russian legislation in terms of defining medical criteria of incapacity and limited capacity is in line with modern medical terminology to a far greater extent. At the same time, we agree with the authors who believe that a temporary state of inability to understand one's actions in the course of transaction or infliction of harm (incapacity) can be caused not only by mental disorders but also by other psychiatric conditions. Thus, M.V. Bobrova defines incapacity as a temporary civil state of the individuals' disability to give rise to civil consequences by their behavior because of a mental disorder or other psychiatric condition unless otherwise is provided in the act of law or follows from the nature of behavior (Bobrova, 2015). Therefore, the German approach is preferable with regard to the terminological nomination of a medical criterion of a temporary state of inability to understand one's actions in the course of transaction or infliction of harm.

3. Mental disorders or other psychiatric conditions should lead to failure in understanding of the meaning of one's actions or controlling them fully or partially (psychological attribute).

According to I.A. Mikhailova, currently legal regulation of capacity and its limitations in foreign countries has its own peculiar characteristics. Yet, the reasons of recognizing the citizen as incapacitated coincide in most cases. These reasons are primarily mental diseases (dementia, mental illness, psychiatric condition, intellectual impairment, etc.) in case the nature and severity of such diseases deprive the citizen of a possibility to understand his/her actions and control them (Mikhailova, 2011). For 
example, $\S 104$ of the Civil Code of Germany stipulates that a person is incapacitated if he/she is "in a state of a painful mental disorder that excludes the freedom of expression if this state is not temporary by its nature".

Despite different terminology the nature of a psychological attribute of the analyzed statuses both in Russia and in Germany is the same. It is in full or temporary inability to understand one's actions. Yet, in the novel of Article 30 of the Civil Code of the Russian Federation on limited capacity caused by a mental disorder a psychological attribute is defined differently as a failure to understand the meaning of one's actions or control them without the help of the others. Such a definition is subject to serious criticism in Russia. In particular, M.V. Bobrova believes that the legislator's approach to the psychological criterion of limited capacity cannot be assumed. First, the criterion mentioned does not comply with medical and legal developments. Both psychiatrists and legislators define it as an inability to fully understand the meaning of one's actions. Secondly, the representatives of psychiatry have repeatedly pointed out that the proposed approach is simplified and does not comply with the requirements of the Convention on the rights of persons with disabilities. In their opinion, the following wording would be the most correct: "cannot fully understand the meaning of one's actions and control them and (or) periodically loses the ability to understand the meaning of one's actions or control them". Without the addition mentioned above the institute of incapacitation does not apply to the whole group of citizens who periodically fail to control their behavior because of a mental disorder. The author believes that Article 30 of the Civil Code of the Russian Federation must be brought into line with medical and legal research. For this the inability to fully understand the meaning of one's actions or control them caused by a mental disorder should be stated as a psychological criterion of limited capacity. In addition, this article should indicate the possibility of incapacitation when the ability to understand one's actions is periodically lost (Bobrova, 2015).

The analysis of the civil legislation of Russia and Germany on legal statuses caused by a mental disorder results in the conclusion about their common characteristic features: a) they are of a legal status; b) they are primarily caused by a mental disorder; c) they indicate a person's inability to understand the meaning of one's actions or to control them fully or partially. However, there are differences in legislative approaches: a) the number of legislatively fixed legal conditions is different; b) the terminology for a medical criterion of these statuses is different; c) the institute of incapacitation is legislated differently, etc. Yet, this should not impede the improvement of the civil law of Russia and Germany regarding the above mentioned legal statuses; it should be focused on internationally recognized standards of human rights and take into account the countries' accumulated positive practice in this field.

International statistical classification of diseases and related health problems. (1995). Vol. 1 (Parts 1 and 2). Moscow. Hereinafter referred to as MSCD-10.

\section{References}

Blinova (Shepel), T.V. (1987). Pravovoe polozhenie nedeesposobnykh vsledstvie psikhicheskogo rasstroistva po sovetskomu grazhdanskomu i semeinomu zakonodatel'stvu: dis. ... kand. iurid. nauk [The legal Status of Those Who are Incapable Due to a Mental Disorder under the Soviet Civil and Family Law]: thesis of candidate of legal sciences. Tomsk, $237 \mathrm{p}$. 
Bobrova, M.V. (2015). Deesposobnost' i ee vliianie na dinamiku deliktnykh obiazatel'stv: avtoref: dis. ... kand. iurid. nauk [Capability and Its Impact on the Dynamics of Tort Liabilities]: abstract of the thesis of candidate of legal science. Tomsk, $26 \mathrm{p}$.

Ivanova, L.Ia. (1993). Grazhdanskaia pravosub'ektnost' lits, stradaiushchikh psikhicheskim rasstriystvom: avtoref: dis. ... kand.iyurid. nauk [Civil Legal Personality of IndividualsSsuffering from a Mental Disorder]: abstract of the thesis of candidate of legal sciences. Ekaterinburg, $26 \mathrm{p}$.

Mikhailova, I.A. (2011). Priznanie grazhdanina nedeesposobnym i ogranichenno deesposobnym v sovremennykh zarubezhnykh gosudarstvakh [Recognition of a Citizen as Legally Incapable and of Limited Capacity in Modern Foreign States], In Iurist [The Lawyer], 23.

Shepel, T.V. (2006). Delikt i psikhicheskoe rasstroistvo: tsivilisticheskii aspect: dis. ... d-ra iurid. nauk [The Tort and Mental Disorder: the Civil Aspect]: thesis of doctor of legal sciences. Tomsk, $342 \mathrm{p}$.

\title{
Правовые состояния лиц, обусловленные психическими нарушениями, по гражданскому законодательству России и Германии
}

Т.В. Шепель

Новосибирский национальный исследовательский государственный университет Россия, 630090, Новосибирск, ул. Пирогова, 1

\begin{abstract}
В статье дается сравнительная характеристика правовых состояний, обусловленных психическим расстройством, предусмотренных законодательством России и Германии: недееспособности, ограниченной дееспособности, временной неспособности понимать значение своих действий или ими руководить в момент совершения сделки или причинения вреда. Анализ Гражданского кодекса Российской Федераџии и Германского гражданского уложения показал, что данные состояния в России и Германии имеют общие черты: а) они являются правовыми состояниями; б) обусловлены, прежде всего, психическим расстройством; в) свидетельствуют о неспособности лиияа понимать значение своих действий или ими руководить. Вместе с тем существуют и различия в правовой регламентации данных состояний: а) неодинаково количество легально закрепленных правовых состояний; б) используется различная терминология для обозначения медииинского критерия этих состояний; в) по-разному закреплен институт ограничения дееспособности и т.д. Однако это не препятствует совершенствованию норм гражданского права России и Германии о названных правовых состояниях с учетом положительного опыта обеих стран.
\end{abstract}

Ключевые слова: недееспособность, ограниченная дееспособность, временная неспособность осознавать свои действия при совершении сделок и причинении вреда в России и Германии, психическое расстройство.

Научная специальность: 12.00.00 - юридические науки. 